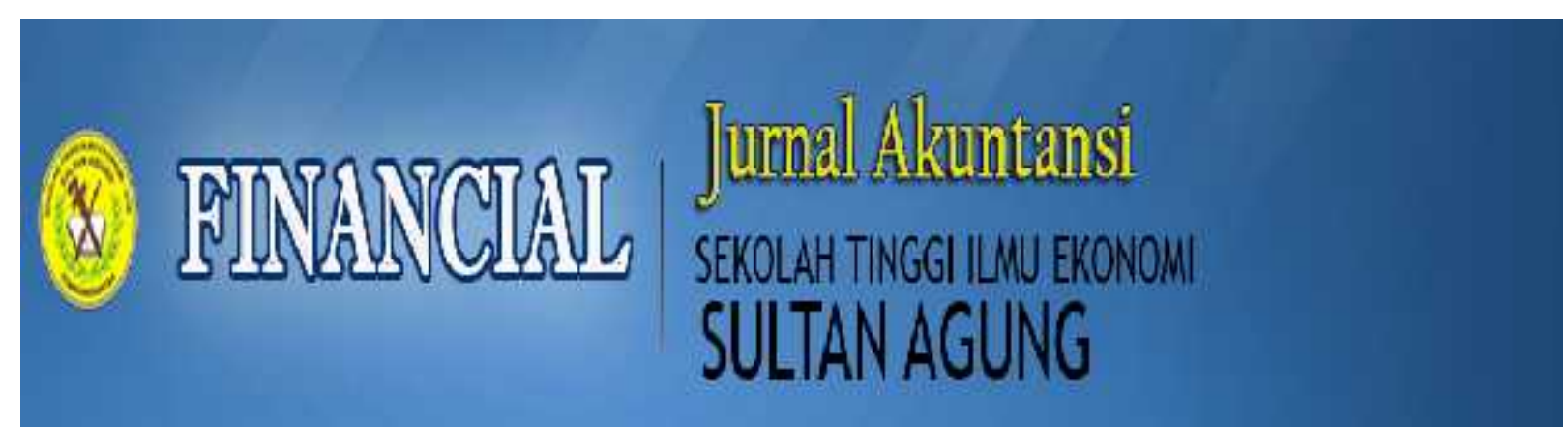

\title{
PENGARUH PERTUMBUHAN PERUSAHAAN, LIKUIDITAS, DAN PROFITABILITAS TERHADAP NILAI PERUSAHAAN PADA PERUSAHAAN SUB SEKTOR PERTAMBANGAN BATUBARA YANG TERDAFTAR DI BURSA EFEK INDONESIA
}

\author{
Oleh : \\ Nanda Khairani \\ S1 Akuntansi \\ Yansen Siahaan, Elly Susanti, Supitriyani
}

\section{Abstrak}

Tujuan dari penelitian ini adalah 1. Untuk mengetahui gambaran pertumbuhan perusahaan, likuiditas, profitabilitas dan nilai perusahaan pada Perusahaan Sub Sektor Pertambangan Batubara yang terdaftar di Bursa Efek Indonesia. 2. Untuk mengetahui bagaimana pengaruh pertumbuhan perusahaan, likuiditas dan profitabilitas terhadap nilai perusahaan pada Perusahaan Sub Sektor Pertambangan Batubara yang terdaftar di Bursa Efek Indonesia baik secara simultan maupun parsial.

Hasil penelitian ini dapat disimpulkan bahwa 1. Rata-rata pertumbuhan perusahaan cenderung meningkat, likuiditas cenderung meningkat, profitabilitas cenderung meningkat dan nilai perusahaan cenderung menurun. 2. Hasil pengujian dari regresi linier berganda diketahui bahwa pertumbuhan perusahaan, likuiditas dan profitabilitas berpengaruh negatif terhadap nilai perusahaan. 3. Hasil analisis koefisien korelasi dan korelasi determinasi dapat di ambil kesimpulan bahwa hubungan antara pertumbuhan perusahaan, likuiditas, dan profitabilitas terhadap nilai perusahaan rendah dan cukup banyak dipengaruh oleh variabel lain yang tidak dijelaskan dalam penelitian ini. 4. hasil uji hipotesis dapat disimpulkan bahwa likuiditas tidak signifikan terhadap nilai perusahaan, pertumbuhan perusahaan signifikan terhadap nilai perusahaan, dan profitabilitas berpengaruh signifikan terhadap nilai perusahaan.

Saran yang dapat diberikan adalah sebaiknya pertumbuhan mengoptimalkan seluruh aset yang dimiliki, memanfaatkan seluruh modal kerja perusahaan sehingga dapat meningkatkan penjualan, memaksimalkan pengelolaan modal sendiri, memperhatikan peningkatan nilai perolehan laba.

Kata Kunci : Pertumbuhan Perusahaan, Likuiditas, Profitabilitas, dan Nilai Perusahaan

\section{Abstract}

The purpose of this study is 1. To find out the description of the company's growth, liquidity, profitability and company value in the Coal Mining Sub-Sector Company listed on the Indonesia Stock Exchange. 2. To find out the influence of the company's growth, liquidity and profitability on the value of the company in the Coal Mining Sub-Sector Company listed on the Indonesia Stock Exchange both simultaneously and partially.

The results of this study can be concluded as follows 1 . The average company growth tends to increase, liquidity tends to increase, profitability tends to increase and firm value tends to decrease. 2. The test results of multiple linear regression is known that the company's growth, liquidity and profitability negatively affect the value of the company. 3. The results of the analysis of the correlation coefficient and correlation of determination can be concluded that the relationship between company growth, liquidity, and profitability to firm value is low and is quite much influenced by other variables that did not described in this study. 4. Hypothesis test results can be concluded that liquidity is not significant to the value of the company, the company's growth is significant to the value of the company, and profitability has a significant impact on the value of the company.

The result of this research is that it is better to optimize growth of all assets owned, utilize all the company's working capital so that it can increase sales, maximize the management of own capital, pay attention to the increase in profit value.

Keywords: Company Growth, Liquidity, Profitability, and Company Value

\section{A. PENDAHULUAN}

\section{Latar Belakang Masalah}

Nilai perusahaan dapat mencerminkan kinerja yang dapat mempengaruhi persepsi investor terhadap perusahaan. Nilai perusahaan yang tinggi merupakan keinginan setiap pemilik perusahaan karena nilai yang tinggi menunjukkan kemakmuran para pemegang saham. Nilai perusahaan berkaitan dengan harga saham dikarenakan semakin tinggi harga saham maka akan semakin tinggi nilai perusahaan. Nilai buku per saham dapat dihitung sebagai hasil antara ekuitas dengan jumlah saham beredar. Faktorfaktor yang mempengaruhi nilai perusahaan adalah keputusan investasi, keputusan pendanaan, dan keputusan manajemen aset. Pertumbuhan aset adalah kemampuan perusahaan untuk 
meningkatkan ukuran melalui peningkatan aktiva. Pertumbuhan perusahaan tahun sebelumnya digunakan untuk meramalkan pertumbuhan perusahaan pada tahun berikutnya. Sedangkan faktor yang mempengaruhi nilai perusahaan adalah likuiditas. Likuiditas adalah tingkat kemampuan suatu perusahaan dalam memenuhi kewajiban jangka pendeknya. Dan faktor yang mempengaruhi nilai perusahaan adalah profitabilitas. Profitabilitas adalah kemampuan suatu perusahaan untuk menghasilkan laba.

Nilai perusahaan dapat diukur dari berbagai aspek. Salah satunya adalah dengan menggunakan Price to Book Value (PBV). Price to Book Value merupakan perbandingan antara harga per saham dengan nilai buku per saham.

Tabel 1.1

Gambaran rata-rata Pertumbuhan

Perusahaan, Likuiditas, Profitabilitas, dan

Nilai Perusahaan Pada Perusahaan

Sub Sektor Pertambangan Batubara

Yang Terdaftar di Bursa Efek Indonesia Periode 2014-2017

\begin{tabular}{|c|c|c|c|c|}
\cline { 1 - 3 } TAHUN & $\begin{array}{c}\text { Pertumbuhan } \\
\text { Perusahaan }\end{array}$ & Likuiditas & Profitabilitas & $\begin{array}{c}\text { Nilai } \\
\text { Perusah } \\
\text { aan }\end{array}$ \\
\cline { 1 - 4 } $\mathbf{2 0 1 4}$ & 0,0342 & 1,7537 & 0,0982 & 1,7917 \\
\hline $\mathbf{2 0 1 5}$ & 0,1076 & 2,0703 & 0,0947 & 0,8929 \\
\hline $\mathbf{2 0 1 6}$ & $-0,0065$ & 2,7822 & 0,0940 & 1,8562 \\
\hline $\mathbf{2 0 1 7}$ & 0,1395 & 2,4357 & 0,1446 & 0,9596 \\
\hline $\begin{array}{c}\text { Rata- } \\
\text { rata }\end{array}$ & $\mathbf{0 , 0 6 8 7}$ & $\mathbf{2 , 2 6 0 5}$ & 0,1079 & 1,3751 \\
\hline
\end{tabular}

Sumber: www.idx.co.id, data diolah

Berdasarkan Tabel 1.1 diatas dapat dilihat bahwa pertumbuhan perusahaan Sub Sektor Pertambangan Batubara yang Terdaftar di Bursa Efek Indonesia selama periode 20142017 mengalami fluktuasi cenderung meningkat., sedangkan rata-rata nilai perusahaan mengalami fluktuasi dan cenderung menurun.

\section{Rumusan Masalah}

a. Bagaimana gambaran pertumbuhan perusahaan, likuiditas profitabilitas, dan nilai perusahaan pada Perusahaan Sub Sektor Pertambangan Batubara yang terdaftar di Bursa Efek Indonesia.

b. Bagaimana pengaruh pertumbuhan perusahaan, likuiditas dan profitabilitas terhadap nilai perusahaan pada Perusahaan Sub Sektor Pertambangan Batubara yang terdaftar di Bursa Efek Indonesia baik secara simultan maupun parsial.

3. Tujuan Penelitian

a. Untuk mengetahui gambaran pertumbuhan perusahaan, likuiditas, profitabilitas dan nilai perusahaan pada Perusahaan Sub Sektor Pertambangan Batubara yang terdaftar di Bursa Efek Indonesia. b. Untuk mengetahui bagaimana pengaruh pertumbuhan perusahaan, likuiditas dan profitabilitas terhadap nilai perusahaan pada Perusahaan Sub Sektor Pertambangan Batubara yang terdaftar di Bursa Efek Indonesia baik secara simultan maupun parsial.

\section{Metodologi Penelitian}

Penelitian ini menggunakan data sekunder dengan cara mengakses dari situs http://www.idx.co.id. Desain penelitian ini adalah penelitian kepustakaan (library research). Teknik analisa data yang digunakan adalah uji asumsi klasik, analisa deskriptif kualitatif, analisa deskriptif kuantitatif.

\section{B. LANDASAN TEOR}

\section{Analisa Laporan Keuangan}

Menurut Faud (2016:7), "analisis laporan keuangan merupakan kumpulan proses analisis yang merupakan bagian dari analisis bisnis.

Sedangkan Subramanyam dan John (2010:4) mendefinisikan sebagai, "aplikasi dari alat dan teknik analisis untuk laporan keuangan bertujuan umum dan data-data yang berkaitan untuk menghasilkan estimasi (perkiraan) dan kesimpulan yang bermanfaat dalam analisis bisnis".

\section{Tujuan Laporan Keuangan}

Menurut Hanafi dan Halim (2016:6), tujuan analisis laporan keuangan adalah investasi saham, Pemberian Kredit, Kesehatan Pemasok, Kesehatan Pelanggan, Kesehatan perusahaan ditinjau karyawan, Pemerintah, Analisis Internal, Analisis Pesaing, Penilaian Kerusakan.

Sedangkan tujuan laporan keuangan menurut Munawir (2010:31) yakni alat yang esensial untuk memperoleh informasi sehubungan dengan posisi keuangan dan hasil-hasil yang telah dicapai emiten yang bersangkutan.

\section{Rasio Keuangan}

Menurut Horne dan John (2012:163), "rasio keuangan merupakan indeks yang menghubungkan dua angka akuntansi dan diperoleh dengan membagi satu angka dengan angka lainnya".

Menurut Kasmir (2010:93), "rasio keuangan merupakan kegiatan membandingkan angkaangka yang ada dalam laporan keuangan dengan cara membagi satu angka dengan angka lainnya".

\section{Pertumbuhan Perusahaan}

Menurut Sartono (2001:248), "perusahaan yang sedang tumbuh sebaiknya tidak membagikan laba sebagai deviden tetapi lebih baik digunakan untuk ekspansi. Potensi pertumbuhan in dapat diukur dari biaya penelitian dan pengembangan. Semakin besar R\&d cost nya yang berarti ada prospek perusahaan untuk tumbuh." 
Menurut Atmaja (2008:274), "menyatakan bahwa perusahaan yang tinggi tingkat pertumbuhannya pada umumnya tergantung pada modal dari luar perusahaan. Pada perusahaan dengan tingkat pertumbuhan yang rendah kebutuhan baru relatif kecil sehingga dapat dipenuhi dari laba ditahan."

\section{Likuiditas}

Menurut Sudana (2011:21), mengemukakan "rasio likuiditas (liquidity ratio) yaitu rasio yang mengukur kemampuan perusahaan untuk memenuhi kewajiban keuangan jangka pendek.

Sedangkan menurut Kasmir (2010:110), "rasio likuiditas (liquidity ratio) merupakan rasio yang menggambarkan kemampuan perusahaan memenuhi kewajiban hutang jangka pendek".

\section{Profitabilitas}

Menurut Brigham dan Joel (2012:146), "profitabilitas adalah rasio yang mencerminkan hasil akhir dari seluruh kebijakan keuangan dan keputusan dari pengaruh likuiditas, manajemen aset, dan rasio utang pada hasil operasi."

Menurut Astuti (2004:36), "rasio profitabilitas adalah kemampuan suatu perusahaan untuk menghasilkan laba

\section{Nilai Perusahaan}

Menurut Brigham dan Joel (2012:152), "Price to Book Value sama dengan satu, yaitu harga saham dari perusahaan tersebut seharusnya dihargai oleh investor sesuai dengan nilai bukunya". Sedangkan menurut Hartono (2010:487), "nilai perusahaan adalah nilai jual sebuah perusahaan sebagai suatu bisnis yang sedang beroperasi".

\section{Pengaruh Pertumbuhan}

Perusahaan, Likuiditas, dan

Profitablitas terhadap Nilai

\section{Perusahaan}

Menurut Sartono (2001:248), "perusahaan yang sedang tumbuh sebaiknya tidak membagikan laba sebagai deviden tetapi lebih baik digunakan untuk ekspansi. Potensi pertumbuhan in dapat diukur dari biaya penelitian dan pengembangan. Semakin besar R\&d cost nya yang berarti ada prospek perusahaan untuk tumbuh."

Menurut Brigham dan Joel (2010:150) yang menyatakan bahwa "jika rasio likuiditas, manajemen aset, manajemen utang dan profitabilitas semuanya terlihat baik dan apabila kondisi ini berjalan secara terus menerus secara stabil maka rasio nilai pasar juga akan tinggi, harga saham kemungkinan tinggi sesuai dengan yang diperkirakan dan manajemen telah melakukan pekerjaannya dengan baik sehingga sebaiknya mendapat imbalan".
C. PEMBAHASAN
1. Analisis
a. Analisis Deskripsi Kualitatif

1) Gambaran Pertumbuhan Perusahaan Terhadap Nilai Perusahaan pada Perusahaan Sub Sektor Pertambangan Batubara yang Terdaftar di Bursa Efek Indonesia Periode 2014-2017

Berikut ini gambaran pertumbuhan perusahaan Sub Sektor Pertambangan Batubara, yang diukur dengan Growth.

Tabel 2

Gambaran GA Perusahaan Sub Sektor Pertambangan Batubara, Periode 2014-2017

\begin{tabular}{|c|c|c|c|c|c|}
\hline $\begin{array}{c}\text { Kode } \\
\text { Emiten }\end{array}$ & $\begin{array}{c}\mathbf{2} 014 \\
\text { (kali) }\end{array}$ & $\begin{array}{c}\mathbf{2 0 1 5} \\
\text { (kali) }\end{array}$ & $\begin{array}{c}\mathbf{2 0 1 6} \\
\text { (kali) }\end{array}$ & $\begin{array}{c}\mathbf{2 0 1 7} \\
\text { (kali) }\end{array}$ & $\begin{array}{c}\text { Rata-Rata } \\
\text { (kali) }\end{array}$ \\
\hline ADRO & $(0,0237)$ & 0,0323 & 0,0650 & 0,0448 & 0,0296 \\
\hline GEMS & $(0,0250)$ & 0,3466 & 0,0216 & 0,2795 & 0,1557 \\
\hline ITMG & $(0,0416)$ & $(0,0005)$ & 0,0000 & 0,1324 & 0,0226 \\
\hline KKGI & $(0,0421)$ & 0,0975 & $(0,0244)$ & 0,0732 & 0,0260 \\
\hline MYOH & 0,1186 & 0,0951 & $(0,1105)$ & $(0,0795)$ & 0,0059 \\
\hline PTBA & 0,2685 & 0,1406 & 0,0996 & 0,1836 & 0,1731 \\
\hline TOBA & $(0,0150)$ & 0,0417 & $(0,0972)$ & 0,3424 & 0,0680 \\
\hline $\begin{array}{l}\text { Rata- } \\
\text { rata }\end{array}$ & $\mathbf{0 , 0 3 4 2}$ & $\mathbf{0 , 1 0 7 6}$ & $\mathbf{( 0 , 0 0 6 5 )}$ & $\mathbf{0 , 1 3 9 5}$ & $\mathbf{0 , 0 6 8 7}$ \\
\hline \multicolumn{7}{|c|}{ Nilai Minimum GA } \\
\hline \multicolumn{5}{|c|}{ Nilai Maximum GA } & $\mathbf{0 , 0 0 0}$ \\
\hline
\end{tabular}

Sumber : Data Diolah

Berdasarkan Gambar 2 di atas, diketahui bahwa pertumbuhan perusahaan mengalami fluktuasi dan cenderung meningkat.

2) Gambaran Likuiditas Perusahaan Sub Sektor Pertambangan Batubara Periode 2014-2017

Berikut ini Likuiditas Perusahaan Sub Sektor Pertambangan Batubara yang diukur dengan rasio Current Ratio disajikan dalam Tabel 3:

Tabel 3

Gambaran CR pada Perusahaan Sub Sektor Pertambangan Batubara Periode 2014-2017

\begin{tabular}{|c|c|c|c|c|c|}
\hline $\begin{array}{c}\text { Kode } \\
\text { Emiten }\end{array}$ & $\begin{array}{l}2014 \\
\text { (kali) }\end{array}$ & $\begin{array}{l}2015 \\
\text { (kali) }\end{array}$ & $\begin{array}{l}2016 \\
\text { (kali) }\end{array}$ & $\begin{array}{l}2017 \\
\text { (kali) }\end{array}$ & $\begin{array}{c}\text { Rata-Rata } \\
\text { (kali) }\end{array}$ \\
\hline ADRO & 1,6417 & 2,4039 & 2,4710 & 2,5594 & 2,2690 \\
\hline GEMS & 2,2060 & 2,7943 & 3,7743 & 1,6823 & 2,6142 \\
\hline ITMG & 1,5640 & 1,8018 & 2,2568 & 2,4335 & 2,0140 \\
\hline KKGI & 1,6858 & 2,2195 & 4,0509 & 3,5405 & 2,8742 \\
\hline $\mathrm{MYOH}$ & 1,8620 & 2,3296 & 4,2984 & 2,8451 & 2,8338 \\
\hline $\begin{array}{l}\text { PTBA } \\
\end{array}$ & 2,0751 & 1,5435 & 1,6558 & 2,4634 & 1,9345 \\
\hline TOBA & 1,2412 & 1,3995 & 0,9678 & 1,5256 & 1,2836 \\
\hline $\begin{array}{l}\text { Rata- } \\
\text { rata }\end{array}$ & 1,7537 & 2,0703 & 2,7822 & 2,4357 & 2,2605 \\
\hline \multicolumn{5}{|c|}{ Nilai Minimum G } & 0,9700 \\
\hline
\end{tabular}

Sumber : Data Diolah

Berdasarkan Gambar 3 di atas, diketahui bahwa likuiditas berfluktuasi cenderung meningkat.

3) Gambaran Profitabilitas Perusahaan Sub Sektor Pertambangan Batubara Periode 2014-2017

Berikut ini profitabiitas Perusahaan Sub Pertambangan Batubara yang diukur dengan menggunakan rasio ROA disajikan dalam Tabel 4 berikut ini:

Tabel 4

Gambaran ROA Perusahaan Sub Sektor Pertambangan Batubara Periode 2014-2017

\begin{tabular}{|c|c|c|c|c|c|}
\hline $\begin{array}{c}\text { Kode } \\
\text { Emiten }\end{array}$ & $\begin{array}{c}\mathbf{2 0 1 4} \\
\text { (kali) }\end{array}$ & $\begin{array}{c}\mathbf{2 0 1 5} \\
\text { (kali) }\end{array}$ & $\begin{array}{c}\mathbf{2 0 1 6} \\
\text { (kali) }\end{array}$ & $\begin{array}{c}\mathbf{2 0 1 7} \\
\text { (kali) }\end{array}$ & $\begin{array}{c}\text { Rata-Rata } \\
\text { (kali) }\end{array}$ \\
\hline ADRO & 0,286 & 0,0253 & 0,0522 & 0,0787 & 0,0462 \\
\hline GEMS & 0,0341 & 0,0057 & 0,0926 & 0,2034 & 0,0840 \\
\hline ITMG & 0,1568 & 0,1706 & 0,1080 & 0,1860 & 0,1553 \\
\hline KKGI & 0,0804 & 0,0960 & 0,0960 & 0,1279 & 0,1001 \\
\hline MYOH & 0,1321 & 0,1534 & 0,1444 & 0,0904 & 0,1301 \\
\hline PTBA & 0,1363 & 0,1206 & 0,1090 & 0,2068 & 0,1432 \\
\hline
\end{tabular}




\begin{tabular}{|l|c|c|c|c|c|}
\hline TOBA & 0,1191 & 0,0911 & 0,0558 & 0,1188 & 0,0962 \\
\hline $\begin{array}{l}\text { Rata- } \\
\text { rata }\end{array}$ & $\mathbf{0 , 0 9 8 2}$ & $\mathbf{0 , 0 9 4 7}$ & $\mathbf{0 , 0 9 4 0}$ & $\mathbf{0 , 1 4 4 6}$ & $\mathbf{0 , 1 0 7 9}$ \\
\hline \multicolumn{5}{|c|}{ Nilai Minimum GA } \\
\hline \multicolumn{5}{|c|}{ Nilai Maximum GA } & $\mathbf{0 , 0 1 0 0}$ \\
\hline \multicolumn{5}{|c|}{} \\
\hline
\end{tabular}

Sumber : Data Diolah

Berdasarkan Gambar 4 di atas, diketahui bahwa Profitabilitas selama periode penelitian berfluktuasi dan cenderung mengalami peningkatan.

\section{4) Gambaran Nilai Perusahaan Perusahaan}

Sub Sektor Pertambangan Batubara

Periode 2014-2017

Berikut ini Nilai Peruahaan Perusahaan Sub Pertambangan Batubara yang diukur dengan menggunakan rasio PBV disajikan dalam Tabel 5 berikut ini:

Tabel 5

Gambaran PBV pada Perusahaan Sub Sektor

Pertambangan Batubara Periode 2014-2017

\begin{tabular}{|c|c|c|c|c|c|}
\hline $\begin{array}{c}\text { Kode } \\
\text { Emiten }\end{array}$ & $\begin{array}{c}\mathbf{2} \text { (214 } \\
\text { (kali) }\end{array}$ & $\begin{array}{c}\mathbf{2 0 1 5} \\
\text { (kali) }\end{array}$ & $\begin{array}{c}\mathbf{2 0 1 6} \\
\text { (kali) }\end{array}$ & $\begin{array}{c}\mathbf{2 0 1 7} \\
\text { (kali) }\end{array}$ & $\begin{array}{c}\text { Rata-Rata } \\
\text { (kali) }\end{array}$ \\
\hline ADRO & 0,8168 & 0,3537 & 1,0591 & 1,0760 & 0,8264 \\
\hline GEMS & 3,8186 & 2,3291 & 4,2099 & 0,2918 & 2,6623 \\
\hline ITMG & 1,5541 & 0,5619 & 1,5639 & 1,8018 & 1,3704 \\
\hline KKGI & 1,1190 & 0,3966 & 1,3226 & 0,2699 & 0,7770 \\
\hline MYOH & 1,0072 & 0,8995 & 0,9625 & 1,1253 & 0,9986 \\
\hline PTBA & 3,1806 & 1,0749 & 2,6135 & 0,3933 & 1,8156 \\
\hline TOBA & 1,0457 & 0,6349 & 1,2617 & 1,7588 & 1,1753 \\
\hline Rata-rata & $\mathbf{1 , 7 9 1 7}$ & $\mathbf{0 , 8 9 2 9}$ & $\mathbf{1 , 8 5 6 2}$ & $\mathbf{0 , 9 5 9 6}$ & $\mathbf{1 , 3 7 5 1}$ \\
\hline \multicolumn{7}{|c|}{ Nilai Minimum GA } & $\mathbf{0 , 2 7 0 0}$ \\
\hline \multicolumn{7}{|c|}{ Nilai Maximum GA } & $\mathbf{3 , 8 2 0 0}$ \\
\hline
\end{tabular}

Sumber : Data Diolah

Berdasarkan Gambar 5.5 di atas,

diketahui bahwa Price to book value

berfluktuasi dan cenderung menurun.

b. Analisis Deskrisptif Kuantitatif

\section{1) Regresi Linier Berganda}

Analisis regresi linier berganda pada penelitian menggunakan SPSS versi 21 dapat terlihat pada Tabel 6 .

Tabel 6

Hasil Analisis Regresi Linier Berganda

\begin{tabular}{|c|c|c|c|}
\hline \multirow[t]{2}{*}{ Model } & \multicolumn{2}{|c|}{$\begin{array}{l}\text { Unstandardized } \\
\text { Coefficients }\end{array}$} & \multirow{2}{*}{$\begin{array}{c}\begin{array}{c}\text { Standardized } \\
\text { Coefficients }\end{array} \\
\text { Beta }\end{array}$} \\
\hline & B & $\begin{array}{l}\text { Std. } \\
\text { Error }\end{array}$ & \\
\hline (Constant) & 1,379 & ,711 & \\
\hline $1 \mathrm{GA}$ & 1,696 & 1,880 & 179, \\
\hline CR & ,193 & ,226 & ,159 \\
\hline ROA & $-5,415$ & 3,826 &,- 279 \\
\hline
\end{tabular}

Sumber: Hasil Pengolahan Data

Berdasarkan Tabel 6, model persamaan regresi yang diperoleh adalah sebagai berikut:

$\hat{Y}=1,379+1,696 X_{1}+0,193 X_{2}-5,415 X_{3}$

Artinya Pertumbuhan perusahaan dan likuiditas berpengaruh positif, sedangkan profitabilitas berpengaruh negatif terhadap nilai perusahaan pada perusahaan Sub Sektor Pertambangan Batubara yang Terdaftar di

Bursa Efek Indonesia periode 2014-2017.

2) Koefisien Korelasi dan Determinasi

Tabel 7

Koefisien Korelasi dan Koefisien Determinasi

\begin{tabular}{|l|c|r|c|c|}
\hline Model & $\mathrm{R}$ & $\begin{array}{c}\mathrm{R} \\
\text { Square }\end{array}$ & $\begin{array}{c}\text { Adjusted } \mathrm{R} \\
\text { Square }\end{array}$ & $\begin{array}{c}\text { Std. Error of the } \\
\text { Estimate }\end{array}$ \\
\hline 1 &, $329^{\mathrm{a}}$ &, 108 &,-003 & 1,02087268 \\
\hline
\end{tabular}

Sumber: Hasil Pengolahan Data

Berdasarkan hasil koefisien korelasi pada Tabel 6 atas diperoleh nilai korelasi $(r)=$
0,329 yang artinya bahwa terdapat hubungan yang rendah antara variabel pertumbuhan perusaahaan, likuiditas, dan profitabilitas terhadap nilai perusahaan. Sementara koefisien determinasi (R) 0,108 terhadap nilai perusahaan dengan proksi Pertumbuhan Perusahaan, Likuiditas dengan proksi Current Ratio, dan profitabilitas dengan proksi Return On Assets (ROA). Hal ini berarti nilai perusahaan dapat dijelaskan oleh pertumbuhan perusahaan, likuiditas, dan profitabilitas sebesar 10,8\% sedangkan sisanya $89,2 \%$ dipengaruhi oleh variabel lain yang tidak dijelaskan dalam penelitian ini, misalnya Quick Ratio (QR), Return On Equity (ROE), dan Manajemen Aset.

3) Uji Hipotesis

\section{a) Uji Simultan (Uji F)}

Hasil uji F dapat dilihat pada Tabel 7.

Tabel 7

Hasil Uji F

\begin{tabular}{|l|l|l|}
\hline Model & F & \multicolumn{1}{|c|}{ Sig. } \\
\hline \multicolumn{1}{|c|}{ Regression } &, 972 &, $422^{\circ}$ \\
1 & Residual \\
Total & & \\
\hline
\end{tabular}

Sumber: Hasil Pengolahan Data

Berdasarkan Tabel 7, hasil Uji F yang ditampilkan menunjukkan bahwa nilai $F_{\text {hitung }}$ sebesar 0,972 dan dengan menggunakan tabel $F$ diperoleh nilai $F_{\text {tabel }} 2,95$ dengan tingkat signifikan 0,422 yang lebih besar dari 0,05 atau dapat dikatakan 0,422 >0,005 maka. $\mathrm{H}_{0}$ diterima. Artinya secara simultan pertumbuhan perusahaan, likuiditas, dan profitabilitas berpengaruh tidak signifikan terhadap nilai perusahaan pada Perusahaan Sub Sektor Pertambangan Batubara yang Terdaftar di Bursa Efek Indonesia.

b) Uji Parsial (Uji t)

Hasil uji t dapat dilihat pada Tabel 8. Tabel 8

Hasil Uji t

\begin{tabular}{|l|r|r|r|}
\hline Model & \multicolumn{1}{|c|}{$\begin{array}{c}\text { Standardized } \\
\text { Coefficients }\end{array}$} & \multicolumn{1}{|c|}{$\mathrm{t}$} & Sig. \\
\cline { 2 - 3 } & \multicolumn{1}{|c|}{ Beta } & \\
\hline (Constant) & & 1,938 &, 065 \\
1 GA &, 179 &, 902 &, 376 \\
CR &, 159 &, 817 &, 422 \\
\hline ROA &,- 279 & & \\
\hline
\end{tabular}

Sumber: Hasil Pengolahan Data

Berdasarkan Tabel 5.11 di atas, untuk variabel pertumbuhan perusahaan tingkat kepercayaan $95 \%$ alpha $5 \%$ dan $n=15$ maka $\mathrm{df}=\mathrm{n}-\mathrm{k}-1=28-3-1=24$, dari tabel diperoleh angka $t_{\text {tabel }}$ sebesar 2,0639.

2. Evaluasi

a. Evaluasi Pertumbuhan Perusahaan pada Perusahaan Sub Sektor Pertambangan Batubara Periode 2014-2017

Berdasarkan Gambar 5.2 di atas, diketahui bahwa pertumbuhan perusahaan 
mengalami fluktuasi dan cenderung meningkat Hal ini disebabkan oleh total aset yang selama periode penelitian mengalami peningkatan.

Berdasarkan Tabel 5.4 juga dapat diketahui nilai minimun Growth Assets selama periode penelitian tahun 2014-2017 adalah sebesar 0,0000 terdapat pada PT Indo Tambangraya, Tbk. Hal ini karena perusahaan tidak mengalami pertumbuhan. Sedangkan nilai maksimum Growh Assets selama periode penelitian tahun 2014-2017 adalah sebesar 0,3500 terdapat pada PT Golden Energy Mines, Tbk pada tahun 2015,. Hal ini disebabkan oleh perubahan aset yang berubah setiap tahun dan peningkatan pada akun kas, piutang lain-lain, persediaan dan pajak dibayar dimuka.

Berdasarkan uji t diperoleh nilai $t_{\text {hitung }}$ sebesar 0,902 < t tabel sebesar 2,0639 $(0,902<$ 2,0639) , atau nilai signifikan Pertumbuhan Perusahaan (Growth) 0,376 > 0,05 maka $\mathrm{H}_{0}$ diterima artinya pertumbuhan perusahaan berpengaruh tidak signifikan terhadap nilai perusahaan Sub Sektor Pertambangan Batubara yang Terdaftar di Bursa Efek Indonesia periode 2014-2017. Dengan demikian dapat dinyatakan bahwa hasil penelitian petumbuhan perusahaan sejalan dengan pendapat Riyanto yang telah dikemukakan sebelumnya.

\section{b. Evaluasi Likuiditas pada Perusahaan}

Sub Sektor Pertambangan Batubara Periode 2014-2017

Berdasarkan tabel 5.5, nilai rata-rata likuiditas pada Perusahaan Pertambangan Batubara yang terdaftar di Bursa Efek Indonesia periode 2014-2017 adalah sebesar 2,2605 artinya setiap Rp.1 hutang lancar dijamin oleh aset lancar sebesar Rp. 2,2605.

Berdasarkan uji t diperoleh nilai $t_{\text {hitung }}$ sebesar $0,817<t_{\text {tabel }}$ sebesar 2,0639 $(0,817<$ 2,0639), atau nilai signifikan Pertumbuhan Perusahaan CR $(0,422>0,05)$ maka $\mathrm{H}_{0}$ diterima artinya likuiditas perusahaan berpengaruh tidak signifikan terhadap nilai perusahaan Sub Sektor Pertambangan Batubara yang terdaftar di Bursa Efek Indonesia periode 2014-2017. Dengan demikian dapat dinyatakan bahwa hasil penelitian likuiditas perusahaan tidak sejalan dengan pendapat Brigham dan Joel yang telah dikemukakan sebelumnya.

\section{c. Evaluasi Profitabilitas pada Perusahaan}

\section{Sub Sektor Pertambangan Batubara}

Periode 2014-2017

Berdasarkan Tabel 5.5 juga dapat diketahui nilai minimum Likuiditas selama periode penelitian tahun 2014-2017 adalah sebesar 0,9700 terdapat di PT Toba Bara Sejahtera, Tbk artinya setiap Rp.1 hutang lancar dijamin oleh aset lancar sebesar Rp. 0,9700. Hal ini disebabkan oleh perusahaan yang tidak dapat memenuhi hutang jangka pendeknya yang telah jatuh tempo dan mengalami penurunan pada aset lancarnya.

Berdasarkan uji t diperoleh nilai $t_{\text {hitung }}$ sebesar $0,170<t_{\text {tabel }}$ sebesar 2,0639 $(-1,415<$ $2,0639)$, atau nilai signifikan Pertumbuhan Perusahaan ROA $0,170>0,05$ maka $\mathrm{H}_{0}$ diterima artinya profitabilitas perusahaan berpengaruh tidak signifikan terhadap nilai perusahaan Sub Sektor Pertambangan Batubara yang Terdaftar di Bursa Efek Indonesia periode 2014-2017. Dengan demikian dapat dinyatakan bahwa hasil penelitian profitabilitas perusahaan sejalan dengan pendapat Brigham dan Joel yang telah dikemukakan sebelumnya.

\section{d. Evaluasi Nilai Perusahaan pada}

Perusahaan Sub Sektor Pertambangan

Batubara Periode 2014-2017

Berdasarkan Gambar 5.5 di atas, diketahui bahwa Price to book value berfluktuasi dan cenderung menurun. Hal ini disebabkan nilai buku lebih besar daripada nilai sahamnya. Berdasarkan Tabel 5.7 di atas, nilai rata-rata Price to book value pada Perusahaan Pertambangan Batubara yang terdaftar di Bursa Efek Indonesia periode 2014-2017 adalah sebesar 1,3751 . Artinya harga saham dihargai sebesar 1,3751 kali dari nilai bukunya. Terdapat 3 Perusahaan yang berada di bawah rata-rata yaitu PT Adaro Energy Tbk, PT Samindo Resources, Tbk, PT Toba Bara Sejahtera, Tbk sedangkan perusahaan yang berada di atas rata-rata yaitu, PT Golden Energy Tbk, PT Resources Alam Indonesia Tbk, PT Bukit Asam, Tbk, PT Indo Tambang raya, Tbk.

e. Evaluasi Pengaruh Pertumbuhan Perusahaan, Likuiditas, dan Profitabilitas Terhadap Nilai Perusahaan pada Perusahaan Sub Sektor Pertambangan Batubara Periode 2014-2017

Berdasarkan pengujian koefisien korelasi dan determinasi diketahui bahwa nilai $r$ adalah 0,329 yang berarti terdapat korelasi atau hubungan yang rendah antara variabel nilai perusahaan dengan variabel independent lainnya pertumbuhan perusahaan, likuiditas dan profitabilitas. Sementara koefisien determinasi $(R)$ adalah 0,108 artinya pertumbuhan perusahaan $\left(x_{1}\right)$, likuiditas $\left(x_{2}\right)$ dan profitabilitas $\left(x_{3}\right)$ dapat menjelaskan memberi kontribusi kepada nilai perusahaan (Y) pada Sub Sektor Pertambangan Batubara yang terdaftar di Bursa Efek Indonesia sebesar $10,8 \%$ dan sisanya sebesar dipengaruhi oleh varibabel lain yang tidak dijelaskan dalam penelitian ini.

Berdasarkan uji $F$ diperoleh $F_{\text {hitug }}$ 0,972 dan nilai ini lebih kecil dari $F_{\text {tabel }} 2,0639$ sementara nilai likuiditas 0,422 lebih besar daripada nilai $\alpha$ lebih besar dari nilai $\alpha(0,05)$ atau dapat dikatakan 0,422 >0,05 maka $\mathrm{H}_{0}$ diterima. Hal ini berarti secara simultan pertumbuhan 
perusahaan, Likuiditas, dan Profitabilitas berpengaruh tidak signifikan terhadap nilai perusahaan pada Sub Sektor Pertambangan Batubara yang terdaftar di Bursa Efek Indonesia. Hal ini tidak sejalan dengan penelitian ini.

\section{KESIMPULAN DAN SARAN}

1. Kesimpulan

a. Nilai rata-rata pertumbuhan perusahaan pada Perusahaan Sub Sektor Pertambangan Batubara yang terdaftar di Bursa Efek Indonesia mengalami fluktuasi dan cenderung meningkat. Hal ini disebabkan karena pertumbuhan aset yang cenderung meningkat setiap tahunnya.

b. Nilai rata-rata likuiditas pada Perusahaan Sub Sektor Pertambangan Batubara yang terdaftar di Bursa Efek Indonesia mengalami fluktuasi dan cenderung meningkat. Hal ini disebabkan peningkatan aset lancar sementar liabilitas jangka pendek menurun.

c. Nilai rata-rata profitabilitas pada Perusahaan Sub Sektor Pertambangan Batubara yang terdaftar di Bursa Efek Indonesia mengalami fluktuasi dan cenderung meningkat. Hal ini disebabkan oleh laba bersih mengalami peningkatan sedangkan ekuitas mengalami penurunan.

d. Nilai rata-rata nilai perusahaan pada Perusahaan Sub Sektor Pertambangan Batubara yang terdaftar di Bursa Efek Indonesia mengalami fluktuasi dan cenderung menurun. Hal ini disebabkan nilai buku lebih besar dibandingkan dengan harga saham.

e. Dari hasil pengujian regresi linear diketahui bahwa pertumbuhan perusahaan, likuiditas, dan profitabilitas berpengaruh tidak signifikan terhadap nilai perusahaan pada Perusahaan Sub Sektor Pertambangan Batubara yang terdaftar di Bursa Efek Indonesia periode 2014-2017.

f. Dari hasil uji koefisien korelasi dan determinasi likuiditas terhadap nilai perusahaan diketahui bahwa terdapat hubungan yang rendah antara nilai perusahaan dengan likuiditas dan nilai perusahaan serta lebih banyak dipengaruhi oleh faktor lain yang tidak diteliti dalam penelitian.

g. Dari hasil uji $F$ dapat disimpulkan bahwa secara simultan pertumbuhan perusahaan, likuiditas, dan profitabilitas berpengaruh tidak signifikan terhadap nilai perusahaan pada Perusahaan Sub Sektor Pertambangan Batubara yang Terdaftar di Bursa Efek Indonesia.

h. Dari hasil uji t dapat disimpulkan bahwa secar parsial pertumbuhan perusahaan, likuiditas, dan profitabilitas tidak berpengaruh signifikan terhadap nilai perusahaan pada Sub Sektor
Pertambangan Batubara yang Terdaftar di Bursa Efek Indonesia.

2. Saran

a. Untuk mempertahankan pertumbuhan perusahaan sebaiknya pertumbuhan mengoptimalkan seluruh aset yang dimiliki perusahaan agar dapat meningkatkan kinerja dan kegiatan operasional perusahaan. Dengan demikian pertumbuhan perusahaan semakin baik dan para investor tertarik untuk berinvestasi pada perusahaan tersebut.

b. Untuk mempertahankan nilai likuiditas perusahaan sebaiknya perusahaan mengoptimalkan likuiditas perusahaan. Hal ini dapat dilakukan dengan cara memanfaatkan seluruh modal kerja perusahaan sehingga dapat meningkatkan penjualan.

c. Perusahaan dapat mempertahankan profitabilitas dengan cara memaksimalkan pengelolaan modal sendiri sehingga meningkatkan penjualan, penjualan yang meningkat akan meningkatkan jumlah laba yang diperoleh. Pada umumnya investor tertarik dengan perusahaan yang memiliki kemampuan menghasilkan laba yang baik. Ketertarikan kepada investor akan meningkatkan permintaaan terhadap saham perusahaan, yang pada akhirnya meningkatkan harga saham dan meningkatkan harga perusahaan.

d. Untuk meningkatkan nilai perusahaan, perusahaan lebih memperhatikan peningkatan nilai perolehan laba yang dihasilkan dan juga nilai dividen yang dibagikan kepada para penanam modal harus lebih ditingkatkan. Dengan demikian diharapkan para investor lebih berminat untuk menanamkan modalnya di perusahaan.

e. Bagi peneliti selanjutnya, dikarenakan keterbatasan yang dimiliki penulis maka disarankan untuk peneliti selanjutna yang ingin melakukan penelitin terkait dengan penelitian ini agar meneliti variabel lain yang dapat mempengaruhi nilai perusahaan dan menambah rentang waktu penelitian pada Perusahaan Sub Sektor Pertambangan Batubara yang terdaftar di Bursa Efek Indonesia.

\section{E. DAFTAR PUSTAKA}

Astuti, Dewi. 2004. Manajemen Keuangan Perusahaan. Jakarta: Ghalia Indonesia.

Atmaja, Lukas Setia. 2008. Teori dan Praktek Manajemen Keuangan. Yogyakarta: Ghalia Andi Offset.

Brigham, Eugene F, dan Joel F Houston. 2010.

Dasar-dasar Manajemen Keuangan: Essential of Financial Management, Edisi XI, Buku 1. Jakarta: Salemba Empat. 
Brigham, Eugene F, dan Joel F Houston.2012. Manajemen Keuangan, Buku II, Edisi 11. Jakarta: Salemba Empat.

Faud, M.Ramli, 2016. Analisis Laporan Keuangan Pemerintah Daerah, Bogor: Penerbit Ghalia Indonesia.

Hanafi, Dr. Mamduh M., Prof. Dr. Abdul Halim. 2016. Analisis Laporan Keuangan Edisi ke5. Yogyakarta: UPP STIM YKPN.

Horne, James C. Van and John.M. wachowicz, Jr. 2012. Prinsip-prinsip Manajemen Keuangan, Edisi 13, Jakarta: Salemba Empat.
Kasmir. 2010. Analisis Laporan Keuangan, Edisi VIII. Jakarta: Rajawali Pers.

Munawir 2010. Analisa Laporan Keuangan, Edisi II. Yogyakarta: Liberty

Sartono, Agus. 2001. Manajemen Keuangan dan Teori Aplikasi Yogyakarts : BPFE

Subramanyam, K. R dan John J. Wild. 2010. Analisis Laporan Keuangan: Financial Statement Analysis, Edisi X, Buku Satu. Jakarta: Salemba Empat.

Sudana,I. Made.2011. Manajemen Keuangan Perusahaan: Teori dan Praktek. Jakarta : Erlangga. 